\title{
MULTILATERALISM IN FOREIGN POLICY OF BELARUS: EUROPEAN AND EUARASIAN DIMENSION
}

\author{
Alena A. Dastanka ${ }^{1}$ \\ Belarusian State University (Republic of Belarus)
}

\begin{abstract}
The article builds on the author' comparative analysis of advantages and disadvantages of regional dimensions (both towards the European Union and the CIS region) of Belarusian foreign policy in framework of multilateralism. The lack of political cooperation since 1997 didn't affect a lot the dynamic of economic bilateral cooperation between the EU countries and Belarus (since 1995 the EU is the second trade partner for Belarus after Russian Federation). Contrary, it is growing tendency in the CIS region in certain shift from bilateralism to multilateralism in pursuing national security, political and economic interests. Multilateral regional structures, from the Commonwealth of Independent States (CIS), Eurasian Economic Union (EAEU) between Armenia, Belarus, Kazakhstan and Russian Federation (with membership of post-soviet countries) to Shanghai Cooperation Organization (SCO) with membership of Russia and China and observer status of India, Pakistan, Iran and Mongolia and status of dialogue partner for Belarus, Turkey and Shri-Lanka are gaining the power as the essential modes of regional governance, though being still different in integration priorities of member states and fragile in institutions. Existing difficulties should not overshadow gains within those organizations, nor regional dynamism in general by assuming that regional approach towards multilateral cooperation are thought to be more efficient when dealing with local, subregional and regional challenges and problems.
\end{abstract}

KEYWORDS: multilateralism, Belarus, European Union, Eurasian Economic Union, integration.

JEL CODES: F53, F55, N40

\section{Introduction}

System of international cooperation that has developed over the past 20 years is undergoing a substantial need for modernization and reform. One of the leading schools in the study of international cooperation is multilateralism (opposing state-centric approach to governance), the theoretical foundations of which were developed in the framework of functionalism by J. Caporaso (Caporaso, 1992), as well as in the framework of neofunctionalism by R. Keohane, J. Nye, Jr. (Keohane, Nye, 2011), J. Ruggie (Ruggie, 1993), R. Cox (Cox, 1996). On the example of the various spheres of activity of international organizations the conceptual foundations of multilateralism, its shape, meaning a different context are identified and formulated (Bouchard, 2011), the special features of this approach compared to regionalism are highlighted (Meyer, 2002), interactions between multilateralism and regionalism are revealed (Winters, 2011), the role and future of multilateralism in a changing international system is described (Rapnouil, 2009), criticism of multilateralism is presented (Mearsheimer, 1994). Evaluation of the effectiveness of multilateralism is determined by the emergence of new multilateral actors; the development of new multilateral playing fields; the rise of new concepts of multilateralism (Shorr, 2012; Rapnouil, 2009; The new dynamics..., 2011).

Multilateralism in foreign policy assumes different forms, types and levels of involvement with international organizations, non-state actors in international relations (international non-governmental organi-

1 Alena A. Dastanka - Belarusian State University, Faculty of International Relations, Center for International Studies, Director. Scientific interests: European integration, multilateral cooperation

E-mail: Dostanko@bsu.by; Dostanko@yahoo.com

Tel. +375172095773 
zations, business, financial and industry, public structures). It aimed at building of a common vision and strategic approaches to joint activities in various fields and is based on bilateral and multilateral treaties and agreements, membership (institutional and non-institutional (observer status, etc.), multilateral consultations at the highest level. The creation of the interstate and supranational executive bodies and financing of their activities, short-term forms of multilateral cooperation (joint statements, etc.) are one of the results of multilateralism. The effectiveness of international multilateral cooperation is often assessed in different ways, but its significance is defined as an tool for the implementation of the state interests, and sometimes geopolitical influence in case the full cooperation is impossible or limited by political and / or economic factors (Rapnouil, 2009).

Multilateral cooperation of post-soviet countries is carried out by membership or by other types of presence in global, European and Eurasian regional organizations. Differentiated integration, varying degrees of willingness of states to deepen integration within those or other areas are factors that influenced the decision of states to develop the certain level of cooperation. The Republic of Belarus is a founding member of the United Nations (1945); member of the Non-Aligned Movement (1998); on the level of European regional organizations - member of the Organization for Security and Cooperation in Europe (1992), cooperation with the European Union in the framework of the Eastern Partnership (2009), the Council of Europe (the Special Guest status was granted in 1992 and suspended in 1997 till now), cooperation with the North Atlantic Treaty Organization on the basis of annually updated Individual Partnership and Cooperation Program (1997), as well as within the Euro-Atlantic Partnership Council (1992) and the program "Partnership for Peace" (1995); on the level of European sub-regional organizations - member of the Central European Initiative (1996), observer status in the Organization of the Black Sea Economic Cooperation (2005) and Council of the Baltic Sea States (2009); on the level of Eurasian organizations - member of Commonwealth of Independent States (1991), the Eurasian Economic Union (2003), Collective Security Treaty Organization (2002), Union State of Belarus and Russia (1996); dialogue partner status in Shanghai Cooperation Organization (2009).

Problem. Multilateralism could be an important tool of increasing the activity of the Republic of Belarus as a participant in international relations at the global, regional and subregional levels; it can enhance "the competitiveness" of foreign policy and promote the positive international image of the Republic of Belarus.

Purpose. This article will discuss the main issues of cooperation between Belarus in multilateral and bilateral format in the European dimension (on the example of the EU), and in the Eurasian dimension (on the example of CIS, CSTO, the EAEU, the Union State, as well as the SCO).

Object. Cooperation of Belarus with regional governmental organizations.

Tasks:

- identifying of foreign and domestic interests of Belarus' participation in international organizations;

- identification of factors affecting the decision-making on participation of the Republic of Belarus in multilateral cooperation on the example of the European Union, the Eurasian Economic Union and other regional organizations.

Research methods. The following methods were used: content analysis; situational analysis; event analysis; positional method; method of expert evaluations; political forecasting.

\section{European dimension}

The diplomatic relations between Belarus and the EU were established in August 1992. Partnership and Cooperation Agreement (PCA, 1995), Interim (Temporary) trade agreement (ITA, 1996) were signed and ratified by the Belarusian side and seven EU Member States; ratification was suspended by a decision of the European Council in 1997, which is still in effect [General Affairs Council 1997]. The only legal framework for bilateral economic relations is the Agreement between the European Economic Community and the European Atomic Energy Community and the USSR on trade and commercial and economic cooperation (1989), a formal cooperation is carried out only within the framework of the Eastern Partnership (2009). The other key EU initiatives that apply to Belarus are: The European Neighborhood Policy (2004), is not active in Be- 
larus, since the required by this policy agreed action plan for Belarus is not signed; Eastern Partnership (EaP, 2009) consists of a multilateral and bilateral format (action plans, association agreements). Belarus takes part only in the framework of multilateral format. Belarus participates in the environment cooperation in framework of The Northern Dimension, and the European Neighborhood and Partnership Instrument (ENPI), in the EU cross-border cooperation programs "Poland - Ukraine - Belarus", "Latvia - Lithuania - Belarus", and "Baltic Sea Region".

Policy of the European Union towards Belarus is founded on the Council conclusions from October 15, 2012, and is defined as the critical engagement policy and the policy of targeted restrictive measures [Council conclusions 2012]. The following periods in EU-Belarus relations could be identified (with some degree of conditionality): 1994-1997 (active phase, PCA and ITA signed), 1997-2008 (ratification suspended, frozen political relations with developing economic cooperation), 2008-2010 (looking for normalization of relations, visits to Belarus by EU High-Level representatives, European commission opened diplomatic mission in Minsk, joining EaP), 2010-2012 (restrictive measures as the results of the presidential elections in 2010 and the events around them, few political contacts), 2012 - till now (resuming the contacts, negotiations on visa facilitation and readmission agreements, as well as consultations on modernization issues, still no attempts to institutionalize the bilateral relations between the EU and Belarus.).

Both the EU and Belarus recognize the importance of full cooperation, but this goal could be achieved due to a number of conditions: the EU - requirements related to human rights (mainly - to release the political prisoners), Belarus - requirements related to cancelation adopted restrictive measures and the visa restrictions. Despite this, the economic component of bilateral cooperation during the entire period of the EUBelarus is actively developing. Both - the Belarusian side and the EU's official and expert level - stress that there are unconditional areas of mutual interest. They are: economic and trade cooperation, cooperation on customs issues, development of transit infrastructure, energy security, regulation of quality products and the adoption of appropriate standards, the interaction of financial institutions in the field of agriculture and food security, and, of course, cooperation to combat human trafficking and illegal migration. The development of sectorial cooperation is core element of medium-term cooperation between Belarus and the European Union.

Within the framework of the European Neighborhood Instrument (2014-2020) Strategy Paper and Indicative Program for the support of Belarus by the European Union in the 2014-2017 were formulated. It should be emphasized that this document for the first time recognized the intention of Belarus to participate in the Eurasian integration processes (membership in the Customs Union and the Single Economic Space, the Eurasian Economic Union), as well as interest in supporting and strengthening cooperation with the European Union. Within the framework of the European Neighborhood Instrument 71-89 million euros are allocated for Belarus in 2014-2017 to finance projects in three priority sectors: social inclusion (30\%), the environment (25\%), local and regional economic development (25\%) [Programming... Country Strategy paper, 2014].

As we can see, the European Union pays much more attention to the first three priorities. Support for civil society and independent media is $10 \%$ of total funding. For other EaP countries priorities were formulated as well, the share of funding for projects to support civil society in Armenia is $5 \%$, Georgia - $20 \%$, Moldova $5 \%$ of Azerbaijan - $5 \%$, about the same as in Belarus (The Commission..., 2014). Support for civil society has always been part of country strategies, but in percentage terms has always been lower than other priorities: for example, in the Indicative Program for Belarus for 2007-2013 to finance projects in the field of democratic development and management accounted for $30 \%$, and in social and economic development - 70\% (European Neighborhood... Country Strategy paper, 2007-2013).

As it was mentioned above 71-89 million euros for 2014-2017 were allocated for Belarus. Other countries of Eastern Partnership got a much larger amount of support: Armenia - 140-170 mln. euros, Georgia - 335-410 mln. euros, Moldova - 335-410 mln. euros, Azerbaijan - 77.0-94.0 mln. Euros (The Commission..., 2014). These figures show that Belarus is not a country that represents a very high interest to the EU.

Currently, negotiations on visa facilitation and readmission agreements are undergoing; possible signing is expected at the Eastern Partnership Summit in Riga in May this year. In framework of Eastern Partner- 
ship Belarus participated in Heads of State Summits (Warsaw and Vilnius), in the annual meetings of the Ministers of Foreign Affairs, initiated additional panels to the four thematic platforms (economic integration and EU policies, democracy and governance and stability), develop the dialogue on modernization, nongovernmental structures took part in the meetings of the Euronest, as well as in the activities of the Civil Society Forum (EU-Belarus 2013; European dialogue..., 2013).

Recently talking about the warming of relations between the EU and Belarus, some media raised worries (especially in Russian Federation). However, in the expert community and among people expectations of fast improvement of relations with the EU are not high. The reasons for this are the lack of the legal framework and the difficulties in the political sphere. The results of the October 2013 Institute of Sociology, National Academy of Sciences study show that $62.5 \%$ (and in the Brest region $-73.7 \%$ ) of respondents have a positive attitude to improve relations between Belarus and the EU. The results of the July 2014 study showed that $12.2 \%$ of respondents would like to see Belarus to join the EU (the most common of these judgments among young people aged 23-39 years - $24 \%$ ) (Котляров, 2015). The results of polls conducted by nongovernmental IISEPS shows that $58 \%$ of Belarusians do not support to entry Russia and $50 \%$ do not support to entry the EU (Динамика, 2015).

The principle of "less for less, more for more" applied by the EU towards EaP countries violated the integrity of the initiative in many ways and led to a significant differentiation of EU relations with these countries in both bilateral and multilateral formats. Obviously, events in and around Ukraine in 2013-2015 are actually brought this country beyond the Eastern Partnership. The Association Agreement has been signed with Georgia, Moldova and Ukraine (2014), however, the provisions on the establishment of a free trade area with respect to Ukraine will take effect only in 2016 due to the position of the Russian Federation. Negotiations on the signing of the Association Agreement with the Republic of Azerbaijan had been started in 2010, but now Azerbaijan offers EU to consider the possibility of signing a bilateral agreement on strategic cooperation in a number of areas, the protocol on the expansion of Azerbaijan's participation in EU programs. Preparation of an agreement on association and free trade area in Armenia were completed, but not yet signed. The only country with which all questions on visa liberalization were settled is Moldova. With the exception of Belarus, other five EP countries have different kind of unresolved conflicts.

Other factors should be mentioned that influence Belarus on decision-making process on cooperation with the EU. Among them are: progressive formation of the EAEU and Armenia's accession; strong Russian opposition to "western values" and political and economic pressure from the EU; Ukrainian crisis and Crimean issue.

\section{Eurasian dimension}

Belarus takes an active part in the Eurasian integration processes within the framework of the Union State of Russia and Belarus, the Eurasian Economic Union (EAEU), Collective Security Treaty Organization (CSTO), and has the dialogue partner status in the Shanghai Cooperation Organization (SCO).

Construction (stroitelstvo, the term is commonly used) of the Union State continues today, although it is obvious that there are a number of achievements: the Union budget is formed annually (in 2015 the budget is 4, 872 billion Russian rubles, of which 1.705 billion is listed by Belarus), from which the majority goes to fund joint programs and events (36 in 2015), besides the citizens of the two countries have almost the same opportunities for employment, residence, education, medical care and welfare (though nationals of Belarus have the status of a foreign citizen in Russia and vice versa). Significant results have been achieved in the field of defense and security, combating crime, terrorism, a joint regional military force was set up.

The effectiveness of the CIS is often criticized, but in the 1990s the Commonwealth became the main platform to discuss not only issues of multilateral cooperation, but also address the bilateral format for the most of former Soviet republics (except Latvia, Lithuania, Estonia). CIS preserved technological unity of transport and energy infrastructures that work on unified rules; within the Commonwealth there are 72 specialized bodies, analysis of which indicates that most of them are an effective mechanism for multilateral co- 
operation to promote the coordination of joint actions in the vital sectors of the economy, social development, military cooperation, the fight against crime and terrorism, humanitarian cooperation. In 2011 the Treaty "On free-trade area" was signed, the provisions of which are based on the norms and rules of the WTO.

The significant achievement in 1992 was signing of the Collective Security Treaty, which was then transformed into the CSTO and contributed to the establishment of the national armed forces of member-states to ensure adequate external conditions for their independent state building. The main interest of Belarusian membership in the CSTO is strengthening the external borders, growing military cooperation, cooperation in countering modern threats and challenges, the improvement of security in the information sphere, cooperation enhancement in responding to emergencies, cooperation enhancement on peacekeeping issues with the $\mathrm{UN}$, foreign policy cooperation.

Customs Union, then Single Economic Space of Belarus, Kazakhstan and Russia and now Eurasian Economic Union (with Armenia since January 2, 2015, and expecting the Kyrgyz Republic after the Treaty on accession of the Kyrgyz Republic to the Treaty on the EAEU will come into force by May 8, 2015) became the main economic and political project for Belarus (though the economic content is underlined by Russian and Belarusian authorities more often) (Eurasian..., 2015). The movement toward the EAEU has passed quite smoothly politically, but economically - there were and still are a number of negative aspects. As an example - before the signing the treaty of the EAEU there were sectoral exemptions ( 9 groups of goods oil, petroleum products, natural gas, automotive, alcohol, drugs, tobacco, etc.) and more than 700 horizontal exemptions from the Common Customs Code that refer to national legislation. For one hand, we can be optimistic and can agree with the Head of supranational Eurasian Economic Commission (EEC) Victor B. Khristenko who explained this as a result of nedointegratsija (lack of integration). From another hand, we got Eurasian Economic Union with still partial free trade zone and Custom Union, Single Economic Space with some restrictions on free movements of goods, services, capital and people (f.e., there is still border control between Kazakhstan and Russia) and Treaty on EAEU with common policies in the field of tariff and non-tariff regulation, transport and industry, coordination in agricultural policies, in the electricity, gas, oil and petroleum products, and gradual integration of energy markets. Russia is the locomotive of the EAEU, but now the situation is complicated by restrictive measures that Western countries have applied to Russia because of the events in and around Ukraine, as well as the fact that the new Member States, Armenia and possibly the Kyrgyz Republic, experiencing serious economic problems, as well as Belarus, and Kazakhstan.

Nevertheless, for the first time in post-soviet history we got regional organization which is a competitor to the EU and has the potential: with the current supranational body (EEC), the decisions of which are binding and with its own Court. Without going into an economic analysis, it should be noted that the expectations of the Belarusian population from Eurasian integration lie mainly in the economic sphere. The results of the summer 2014 the Institute of Sociology of NAS of Belarus survey "Belarus-2030" showed that the most important positive effects of Belarus' accession to the EAEU include: expansion of markets for Belarusian goods (49.8\% of respondents); opportunity to obtain financial and other support in times of crisis and the global financial instability (44.6\%); obtaining energy at lower prices $(37.4 \%)$; the opportunity to study in the universities of the EAEU (33.8\%); improving access to innovative technologies and exchange of experts $(23.8 \%)$; the creation of a unified legal regime for employment $(15.8 \%)$.

The following negative consequences of Belarus' accession to the EAEU were named: outflow of the most qualified personnel in the countries of EAEC (41.8 \%); increase in customs duties and prices of some commodities(31.9\%); reducing the competitiveness of Belarusian goods and services in the domestic market against the backdrop of goods and services from the EAEC (31.9\%); violation of the stability of the Belarusian economy when entering the EAEC (21.7\%); loss or "blurring" of national culture and tradition ( $8.1 \%)$ (Котляров, 2015).

The success of the future Eurasian Economic Union is associated primarily with step-by-step integration, according to the principles taken from the EU experience - supranationalism, subsidiarity, convergence, flexibility of decisions. In addition, the political will of all the members to move the integration process, as well as transparency of decision making are considered to be very important factors. 
The Customs Union and Single Economic Space/Eurasian Economic Union was regarded by some experts as a challenge to the SCO, because the Member States of CU / CES / EAEU are strategic partners with each other and at the same time with China. The Russian Federation and the Republic of Kazakhstan, and more recently China occupy a special place in the foreign policy priorities of the Belarusian population. Thereby Belarus can benefit by developing bilateral ties, by implementing dialogue partner status of the Shanghai Cooperation Organization, by participating in regional projects.

Bilateral economic relations between Belarus and the SCO countries - members can be summarized as follows. The share of all the SCO member states in the trade of the country is $54.5 \%$. While the share of the Russian Federation - 48.7 \% (the major trade partner of Belarus); China's share of total turnover in Belarus is much less $-3.9 \%$; Kazakhstan's share $-1.5 \%$; Tajikistan $-0.4 \%$; Uzbekistan $-0.1 \%$. The proportion of SCO observers in the turnover of Belarus is $0.8 \%$ (the largest belongs to India, there are no statistics on Afghanistan). The proportion of SCO dialogue partners $-0.9 \%$. Potentially SCO region is an important area for Belarus to diversify export capacity and to increase turnover.

Other major trade partners of Belarus in 2014 were: the European Union - $26.6 \%$ (the largest share United Kingdom, the Netherlands), and Ukraine - 7.8 \% (Внешняя торговля..., 2015).

Implementing dialogue partner status of the Shanghai Cooperation Organization Belarus produced mechanism of interaction with bodies and agencies of the SCO. For Belarus, the economic dimension is a promising one for the cooperation. An example of a project that brought together with support of the SCO Business Council on an equal footing private companies of Russia, Kazakhstan and China, as well as Belarus as SCO dialogue partner, was the creation of a prototype of the first in the CIS multipurpose maritime unmanned complex (Belarusian party has developed software). This project demonstrates the importance of the project partnership as a means of integrating the participating countries, observers and dialogue partners of the SCO. Interaction with the SCO Business Council allowed to implement in a number of large-scale projects in Belarus involving private structures of SCO members. Among them - the current High-Tech Park, offering upscale software and IT-services.

Initiated by the Chinese side projects for the creation of the Economic Belt of the Silk Road, the Maritime Silk Road of XXI century, in fact, represent opportunities for multilateral cooperation of China and member countries, observers, SCO dialogue partners and at the same time give a powerful impetus for joint economic development in Eurasia.

Proposals for Belarus' participation in the project of the Economic Belt of the Silk Road are the following:

- upgrading of two trans-European corridors;

- improving the logistics infrastructure in their territory, including the participation of Chinese companies;

- improvement of road infrastructure, creation of additional transit network with the participation of countries - members of the EU;

- efforts to improve the load trains following from Europe to China; part of Belarusian goods can be sent to Mongolia, whose territory is crossed this way, since today we are also actively developing relations with this country;

- optimizing the delivery of goods;

- using Belarusian airports as transit points for the best technical stops for refueling and maintenance, as well as flight connections to foreign airlines.

The project of the Chinese-Belarusian industrial park "Great Stone", which is focused on the development of engineering, fine chemistry, biomedicine, household appliances and electronics, entered a decisive phase will also occupy an important place the Economic Belt of the Silk Road.

In this regard, taking into account the resumption of the Republic of Belarus application for observer status, participation of the Republic of Belarus in the activities of the Shanghai Cooperation Organization is mutually beneficial and opens up broad prospects for the development of relations with the SCO countries both in multilateral and bilateral formats. 


\section{Conclusion}

For a long time in multilateral cooperation of the Republic of Belarus tendency of the development of both political and economic relations with post-soviet countries prevailed. First of all, this can be explained by the fact that the essential feature of the foreign trade relations of the Republic of Belarus was their primary focus on the Russian market, which was laid in the period of the Soviet Union. Russia's share in the turnover of Belarus ranged from the minimum $43 \%$ in 1993 to a maximum of $60 \%$ in 2001. In 2005-2014 Russia accounted for an average of $47 \%$ of the turnover of Belarus, which has always been the maximum share in the turnover of Belarus. It should be noted that only in 2010 foreign trade turnover reached nearly as well in 2011 exceeded the total (internal Soviet and foreign) import-export goods of Belarusian SSR in 1990 (Внешняя торговля..., 2015). Since 1997 failing in political relations Belarus and the European Union develop economic cooperation: the EU - the second trading partner, and one of the largest donor of international technical assistance. Developing the multi-vector nature of its foreign policy Belarus has established a strategic bilateral partnership with Russia, China and Kazakhstan and developed multilateral ties in Eurasian Economic Union (membership) and in SCO (dialogue partnership status) and through different regional projects, f.e. the Economic Belt of the Silk Road (with China). Membership of Belarus in the EAEU and possible participation in the project of the Economic Belt of the Silk Road, as well as the development of cooperation with the European Union not only do not interfere, but also complement each other. Belarus is consistently advocating a support of integration processes by implementing the idea of "integration of integration", namely non-opposing of Belarus' membership in the Eurasian Economic Union (EAEU to cooperation with the European Union and other international organizations.

\section{References}

Bouchard, C., Peterson, J. (2011). Conceptualising Multilateteralism. Can we all just get Alone? Mercury. E-paper. No. 1, January. Retrieved: http://www.mercury- fp7.net/fileadmin/user_upload/E_paper_no_1_Revised_Version. pdf [access 30.11.2011].

Caporaso, J. A. (1992). International Relations Theory and Multilateralism: The Search for Foundations. International Organization. Summer, Vol. 4, Issue 3, p. 599-632.

Council conclusions on Belarus. (2012). 3191st Foreign Affairs Council meeting Luxembourg, 15 October Retrieved: http://www.consilium.europa.eu/uedocs/cms_data/docs/pressdata/EN/foraff/132836.pdf [access 13.09.2013].

Cox, R. W., Sinclair, T. J. (1996). Approaches to world order. Cambridge University Press.

EU-Belarus. Retrieved: http://eeas.europa.eu/belarus/index en.htm [access 13.09.2013].

Eurasian Economic Union. Retrieved: http://mfa.gov.by/en/organizations/membership/list/aa16658947a49c28.html [access 17.04.2015].

European dialogue on modernisation with Belarusian society. Retrieved: http:/eeas.europa.eu/delegations/belarus/ press_corner/all_news/news/2012/european_dialogue_modernisation_en.htm [access:13.09.2013].

European Neighbourhood and Partnership Instrument. Belarus. Country Strategy paper 2007-2013 and National Indicative programme 2007-2011. Retrieved: http://ec.europa.eu/world/enp/pdf/country/2011_enpi_nip_belarus en.pdf [access 13.09.2013].

General Affairs Council 15 Sept 1997: Council Conclusions on Belarus.

Keohane, R. O., Nye, Jr., J. S. The Club Model of Multilateral Cooperation and the World Trade Organization: Problems of Democratic Legitimacy. Visions of governance in the $21^{\text {st }}$ century. WorkingPaper, No. 4. Retrieved: http://www. hks.harvard.edu/visions/publication/keohane_nye.pdf [access 30.11. 2011].

Mearsheimer, J. J. (1994/95). The False Promise of International Institutions / International Security. Winter, Vol.19, No. 3, p. 5-49.

Meyer, J. S. (2002). Multilateral Cooperation, Integration and Regimes: The Case of International Labor Mobility by Hebrew University of Jerusalem. Working Paper, No. 61, November. Retrieved: http://www.ccis-ucsd.org/PUBLICATIONS/wrkg61.pdf [access 30.11.2011].

Programming of the European neighbourhood Instrument (ENI) - 2014-2020. Strategy Paper and Multiannual Indicative Programm for EU support to Belarus (2014-2017). (2014). Brussel: European External Action Service. European Commission-Directorate general for Development and Cooperation-EuropeAid, $34 \mathrm{p}$.

Rapnouil, M. L. (2009). A European View on the Future of Multilateralism. Washington Quarterly. Summer, Vol. 3, Issue 3, p. 181-196. 
Ruggie, J. G. (1993). Multilateralism matters: The Theory and praxis of an institutional form. Columbia University Press.

Shorr, D. Think-20: Highlights G-20's Informal Multilateralism. World Politics Review. Retrieved: http://worldpoliticsreview.com/articles/11695/think-20-highlights-g-20s-informal-multilateralism [access 13.03.2012].

The Commission sets out cooperation priorities for the Eastern and the Southern Neigbourhood for coming years. (2014). European Commission. Press release. Brussels, 8 September, IP/14/977.

The new dynamics of multilateralism: diplomacy, international organizations, and global governance (2011). Westview Press.

Winters, L. A. (1996). Regionalism versus Multilateralism. The World Bank. Policy Research Working Paper. November, Retrieved: http:/www.unige.ch/ses/ecopo/demelo/Cdrom/RIA/Readings/Winters96.pdf [access 30.11.2011].

Внешняя торговля Республики Беларусь. Retrieved: http:/www.gtk.gov.by/ru/stats/ [access 17.04.2015].

Динамика белорусского общественного мнения по некоторым социально-экономическим и политическим проблемам (по результатам национальных опросов Независимого института социально-экономических и политических исследований, \%). Retrieved: http://iiseps.org/trends/11 [access 17.04.2015].

Котляров, И. В. (2015). Интеграционные процессы в зеркале общественного мнения. Межнациональное согласие и толерантность - ценностная основа евразийской интеграции: мат. межд. научно-практической конференции, Респ. Беларусь, г. Минск, 9 декабря 2014 г. Ин-т философии НАН Беларуси.Минск: Право и экономика, с. 127-136.

\title{
DA UGIAŠALIŠKUMAS BALTARUSIJOS UŽSIENIO POLITIKOJE: EUROPOS IR EURAZIJOS DIMENSIJOS
}

\author{
Alena A. Dastanka \\ Baltarusijos valstybinis universitetas (Baltarusija)
}

\section{Santrauka}

Straipsnyje atlikta Baltarusijos užsienio politikos lyginamoji regioninių dimensijų privalumų ir trūkumų analizè daugiašališkumo kontekste. Nuo 1997 m. ES valstybių ir Baltarusijos politinio bendradarbiavimo trūkumas neturejjo neigiamos įtakos ekonominiam dvišaliam bendradarbiavimui (nuo $1995 \mathrm{~m}$. ES yra antrasis Baltarusijos prekybos partneris po Rusijos). Priešingai, NVS regione pastebima perèjimo tendencija nuo dvišalių santykių ị daugiašalius, siekiant nacionalinio saugumo, paisant politinių ir ekonominių interesų. Nepaisant skirtingų valstybių narių integracijos prioritetų ir silpnų institucijų daugiašalèse regioninèse struktūrose NVS, Eurazijos Ekonominèje Sajungoje (Armėnija, Baltarusija, Kazachstanas, Rusija), Šanchajaus Bendradarbiavimo organizacijoje (Rusija, Iranas su stebėtojais Indijoje, Pakistanas, Iranas, Mongolija ir dialogo partneriais - Baltarusija, Turkija, Šri-Lanka), šios struktūros tampa svarbiomis regioninès valdysenos formomis. Kita vertus, esami sunkumai neturi nustelbti šių organizacijų naudos ir regioninio dinamizmo. Akivaizdu, kad regioninè prieiga daugiašalio bendradarbiavimo link yra gerokai efektyvesnè negu iššūkių ir problemų sprendimas vietiniu, subregioniniu ar regioniniu lygmenimis.

PAGRINDINIAI ŽODŽIAI: daugiašališkumas, Baltarusija, Europos Sajunga, Eurazijos Ekonomine Sajunga, integracija.

JEL KLASIFIKACIJA: F53, F55, N40 